\title{
Hubungan Kompetensi Lulusan Sarjana Ekonomi Syariah dengan Dunia Kerja
}

\author{
ZUL.KIFLI RUSBY* \\ DESWITA MURDIANA*
}

\author{
-Fakultas Agama Islam (FAI) Universitas Islam Riau (UIR) \\ -Fakultas Agama Islam (FAl) Universitas Istam Rekanbaru 28284 \\ e-mail: zulkiflirusby@yahoo.com Hp: 081378436270 \\ **Fakultas Agama Islam (FAI) Universitas Islam Riau (UIR) \\ No. 113 Perhentian marpoyang Pekanbaru 28284
}

\begin{abstract}
Abstrak: Penelitian ini bertujuan untuk mengetahui hubungan kompetensi Lulusan Sarjana Ekonomi Syariah dengan dunia kerja dan untuk mengetahui upaya yang dilakukan Fakultas Agama Islam Universitas Islam Riau Program Srudi Ekonomi Syraiah dalam mempersiapkan kompetensi Lulusan Sarjana Ekonomi Syariah tersebut, sehingga berdaya guna dan memilik kompetensi yang berkualitas. Lokasi penelitian Fakultas Agama Islam Universitas islam Riau Program Studi Ekonomi Syariah. Teknik pengumpulan data misis data yang wancara. Pengolahan data menggunakan SPSS 17.0. Analisis data yeng digunakan Analisis Korelasi Spearman Rank Untuk pengujian hipotesis menggunakan uji signifikansi (uji $\mathrm{t}$ ). Berdasarkan pengujian hipotesis, diketahui bahwa: pertama, hubungan kompetensi Lulusan Sarjana Ekonomi Syariah dengan dunia kerja menunjukkan hubungan yang positif dan signifikan, (uil penelitian, dimana melalui hasil uji signifikansi (uji t) hal ini terbukti dari hasi 6,448 ternyata lebih besar dibandingkan dengan tohel diketang Koefisien Korelasi Spearman sebesar 2,028. Adapun nilai hubunga hubungan "kuat". Sedangkan pengaruh Rank sebesar 0,732 dengan tingkat hubanga Fkonomi Syariah dengan dunia hubungan antara kompetensi Lulusan Sarja sebesar $46,40 \%$ dipengaruhi oleh kerja sebesar 53,
\end{abstract}

Kata Kunci: Kompetensi Lulusan Sarjana Ekonomi Syariah, Dumia Kerja.

\section{PENDAHULUAN}

Perkembangan ekonomi syariah pertama kali dimulai sejak beroperasinya Bank Muamalat Indonesia pada 1 Mei 1992 (berdiri 3 November 1991). Seiring dengan perkembangannya, semakin banyak perbankan konvensional yang membuka
Unit Layanan Syariah (ULS) (Lukman Fauroni, 2006:15).

Perkembangan ekonomi syariah tentu saja mengandung dua hal yang sangat mendasar. Di satu sisi, hal ini merupakan kemajuan dunia ekonomi syariah di dalam persaingannya dengan ekonomi konvensional, sedangkan pada sisi yang lainnya, hal ini menjadi 
tantangan untuk menyatakan bahwa ekonomi syariah telah menjadi salah satu alternatif ekonomi di tengah keterpurukan sistem ekonomi kapitalis dan sosialis yang kurang ramah terhadap kesejahteraan bersama (Akhmad Mujahidin, 2010:23).

Ekonomi syariah telah menjadi pilihan bagi pengembangan ekonomi dunia. Salah satu indikator yang bisa dilihat adalah dengan semakin banyaknya perbankan asing yang membuka layanan bank syariah. Oleh sebab itu, penguatan kelembagaan dan sistem ini harus terus diupayakan agar kelak tidak terjadi kesalahan di dalam pelaksanaannya (Nursyam Sunan Ampel, 2012:1).

Selain itu, tumbuh suburnya ekonomi dan perbankan syariah di Indonesia ternyata juga berimplikasi terhadap terbukanya lapangan pekerjaan di berbagai sektor, baik sektor formal maupun informal dengan sistem yang mengacu kepada sistem ekonomi syariah.

Di tengah arus perkembangan seperti ini, maka diperlukan lembaga sebagai pusat kajian dan pengembangan pendidikan ekonomi syariah. Dalam hal ini, yang semestinya menjadi pusat kajian dan pengembangan ekonomi syariah adalah perguruan tinggi yang memiliki visi dan misi kajian serta pengembangan ekonomi syariah tersebut (Lukman Fauroni, 2006:58).

Qadri Azizi (2003) berpendapat bahwa perguruan tinggi sebagaimana yang dipahami bukanlah hanya sebagai menara gading, perguruan tinggi harus mempunyai standarisasi yang jelas baik pada visi dan misinya, kualifikasi kemampuan dosen-dosennya, kurikulum dan profil kualifikasi out put yang dihasilkannya. Pembidangan keilmuan Perguruan Tinggi Agama Islam pada dasarnya harus mengedepankan aspek metodologi keilmuannya dan disepakati oleh para cendekiawan (intelectual community) (Fauroni, 2006:59).

Oleh karena itu, dalam rangka penyediaan SDM yang dibutuhlcan oleh industri perbankan syariah dan lembaga-lembaga keuangan

lainnya, maka Program Studi (Prodi) Ekonomi Syariah hadir dengan satu tekad yaitu agar menjadi institusi perguruan tinggi yang unsgul berkualitas dan memberikan koniribus terbaiknya dalam menyokong tumbuik kembangnya ekorromi

Indonesia dan dalam

menebarkan sebanyak-banyaknys kemaslahatan untuk bangsa dan negara serta bagi umat Islam khususnya dan rakyat Indonesia umumnya.

Hadirnya Prodi Ekonor

dalam kelembagaan akademiknya, bukanlah dimaksudkan untuk memisahkan secara diametrai antara ilmu ekonomi syariah dengan ekonomi konvensional melainkan lebil bermakna terhadap penggalian dan pengembangan keilmuan dalam bidang ekonomi yang berlandaskan pad wahyu Al-Qur'an dan Hadis.

Sarjana Ekonomi Syariah pat umumnya telah dibekali imu-imin teoritis sekaligus praktis sebaga persiapan untuk menjadi karyawan maupun wirausahawan yang berkaitan dengan penerapan bidang ekonomi syariah islam. Sistem bagi hasil mudharabah dan musyarakah memberikan peluang besar terhadap pilihan menjadi wirausahawan muda yang tangguh. Tentunya, wirausahawan profesional profetik, yang dapat menggabungkan antara nilai profesional kerja dan professional sebagai wirausahawan pada satu sisi dan nilai moralitas kenabian pada sisi lain (Nawawi, 2009:167).

Di sinilah peran strategis yang

- harus dimainkan oleh Perguruan Tinggi Fakultas Agama Islam (FAI) Universitas Islam Riau (UIR), khususnya Prod 
Ekonomi Syariah yang mengambil peran penting dalam mempersiapkan SDM yang akan dibutuhkan dilapangan.
Berdasarkan hasil pra survei di FAI UIR, jumlah lulusan per tahunnya dapat dilihat pada tabel sebagai berikut:

Tabel 1

Perkembangan Jumlah Lulusan Ekonomi Syariah Fakultas Agama Islam Universitas Islam Riau pada Tahun 2004 s/d 2012

\begin{tabular}{cc}
\hline Wisuda & Jumlah Lulusan \\
\hline Tahun 2004 & 4 \\
\hline Tahun 2005 & 6 \\
\hline Tahun 2006 & 3 \\
\hline Tahun 2008 & 1 \\
\hline Tahun 2009 & 15 \\
\hline Tahun 2010 & 10 \\
\hline Tahun 2011 & 14 \\
\hline Tahun 2012 & 8 \\
\hline Total & $\mathbf{6 1}$
\end{tabular}

Sumber Data: Tata Usaha FAl UIR Pekanbaru, 2012.

Dari tabel di atas dapat diketahui bahwa adanya kecendrungan naik turunnya jumlah lulusan per tahunnya. Dapat dilihat pada tahun 2004, jumlah lulusan sebanyak 4 orang. Dan pada tahun 2006, jumlah lulusan mengalami peningkatan dengan jumlah lulusan sebanyak 6 orang. Namun pada tahun 2007 dan 2008, jumlah lulusan mengalami penurunan sebanyak 3 dan 1 orang. Pada tahun 2009 s/d 2011, jumlah lulusan mengalami peningkatan dan penurunan lagi dengan jumlah lulusan sebanyak 15,10 dan 14 orang. Dan pada tahun 2012, jumlah lulusan mengalami penurunan dengan jumlah lulusan sebanyak 8 orang.

Berdasarkan penjelasan latar belakang masalah di atas, maka permasalah penelitian yang ditetapkan penulis yaitu mengenai hubungan atau keterkaitan antara kompetensi Lulusan Sarjana Ekonomi Syariah FAI UIR dengan dunia kerja yang sedang digelutinya dan upaya FAI UIR Prodi Ekonomi Syariah dalam mempersiapkan kompetensi Lulusan Sarjana Ekonomi Syariah tersebut.

Dalam penelitian ini, penulis memfokuskan sarjana hanya kepada
Lulusan Sarjana Ekonomi Syariah FAI UIR tahun 2004 s/d 2012 yang berkecimpung di dunia kerja. Dunia kerja adalah tempat atau tujuan terakhir para sarjana mengabdikan diri setelah lulus dari perguruan tinggi dalam melaksanakan tanggung jawab sosial kepada masyarakat (Antonio, 2001:255).

Berdasarkan batasan masalah yang telah dikemukakan di atas, maka dapat dirumuskan permasalahan sebagai berikut; (1) Apakah ada hubungan yang signifikan antara kompetensi Lulusan Sarjana Ekonomi Syariah dengan dunia kerja?; dan (2) Apa saja Upaya FAI UIR Prodi Ekonomi Syariah dalam mempersiapkan kompetensi Lulusan Sarjana Ekonomi Syariah tersebut?

Penelitian ini bertujuan untuk mengetahui sejauhmana hubungan kompetensi Lulusan Sarjana Ekonomi Syariah dengan dunia kerja dan untuk mengetahui upaya apa saja yang dilakukan FAI UIR Prodi Ekonomi Syariah dalam mempersiapkan kompetensi Lulusan-Sarjana Ekonomi Syariah, sehingga berdaya guna dan memiliki kompetensi yang berkualitas. 
Penelitian ini diharapkan berguna untuk; (1) Mahasiswa dapat mempersiapkan kualitas dan kemampuan diri sebelum bersaing dalam dunia kerja khususnya industri perbankan syariah dan lembagalembaga keuangan syariah lainnya; (2) Bahan penilaian dan acuan bagi FAI UIR khususnya bidang akademik ekonomi syariah untuk mengevaluasi model dan strategi pendidikan ekonomi syariah masa yang akan datang; (3) Penelitian ini diharapkan dapat memberikan kontribusi pada pengembangan teori dan model ilmu ekonomi syariah; dan (4) Dapat dijadikan sebagai bahan informasi bagi pihak-pihak yang berkepentingan yang akan melakukan penelitian dalam bidang yang sama.

\section{KONSEP TEORI}

\section{Teori Mengenai Perguruan Tinggi dan Sarjana}

Berbicara tentang perguruan tinggi tidak terlepas dari manusia, yaitu dosen dan mahasiswa. Dosen adalah pengajar pada perguruan tinggi (Team Pustaka Phoenix, 2008:201). Sedangkan mahasiswa adalah orang yang belajar di perguruan tinggi (Team Pustaka Phoenix, 2008:556). Majunya sebuah Negara sangat bergantung pada sejauh mana perguruan tinggi tersebut mencetak sarjana atau kader-kader pemimpin bangsa. Kampus adalah tempat kegiatan perguruan tinggi berlangsung (Team Pustaka Phoenix, 2008:413). Kampus merupakan suatu unsur yang sangat penting dalam membangun mental dan spiritual suatu bangsa.

Peran perguruan tinggi dalam membina insan intelektual sudah menjadi kenyatasan. Artinya, setelah mahasiswa mengikuti bangku kuliah mereka telah mencoba mempersiapkan dirinya guna membangun bangsanya, baik melalui ide, konsep, maupun tindakan (A. Rani Usman, 2001:ix).

Setiap tahun perguruan tinggi menciptakan dan melahirkan banyak sarjana dalam berbagai disiplin ilmu sehingga beragam pula lapangan pekerjaan serta bermacam peluang yang dapat diisi oleh para sarjana tersebut. Sarjana adalah orang pandai (ahli ilmu pengetahuan), gelar yang dicapai oleh seseorang yang telah menamatkan pendidikan tingkat terakhir di perguruan tinggi (Team Pustaka Phoenix, 2008:764). Untuk memperoleh titel tersebut, mahasiswa menempuh berbagai cara mulai dari persyaratan akademis sampai dengan keperluan lain yang berkaitan dengan perkuliahan ( $A$. Rani Usman, 2001:53).

\section{Hakikat Ekonomi Syariah}

Ekonomi syariah adalah pengetahuan dan penerapan hukum syariah untuk mencegah terjadinya ketidakadilan atas pemanfaatan dan pembuangan sumber-sumber material dengan tujuan untuk memberikan kepuasan manusia serta mengamalkannya sebagai kewajiban kepada Allah dan masyarakat (Zaman, 1984:52) dalam Muhamad (2008:4).

Sedangkan ilmu ekonomi syariah adalah Studi tentang bagaimana individu atau masyarakat memilih dan menggunakan sumber daya yang ada, sekarang atau yang telah ditinggalkan oleh generasi masa lalu, sesuai aturan atau syarak (Al-Qur'an, hadis, atau hukum di bawahnya) yang digunakan untuk memenuhi kebutuhan jasmani dan rohani tanpa adanya eksploitasi sehingga dapat mewujudkan falah (kesejahteraan) bagi individu maupun masyarakat" (Muhamad, 2008:6). 
Jurnal Al-Hikmah Vol. 12. No. 1, April 2015 ISSN 1412-5382 
Asumsi dasar atau norma pokok aturan main dalam proses maupun interaksi kegiatan ekonomi adalah syari'at Islam yang diberlakukan secara menyeluruh (kaffah atau totalitas) baik terhadap individu, keluarga, masyarakat, pengusaha, atau pemerintah dalam memenuhi kebutuhan hidup baik untuk keperluan jasmani maupun rohani. Dari beberapa definisi di atas, dapat disimpulkan bahwa prinsip ekonomi syariah ialah penerapan asas efisiensi dan manfaat dengan tetap menjaga kelestarian lingkungan alam. Motif Ekonomi syariah adalah mencari keberuntungan di dunia dan akhirat oleh manusia selaku khalifah Allah dengan jalan beribadah. Berbeda dengan ekonomi konvensional, ekonomi syariah mendasarkan setiap aktivitas ekonomi pada ketentuan dan sumber ajaran Islam. Nilai-nilai yang terkandung dalam sumber ajaran itu yang menjadi pertimbangan dalam setiap aktivitas ekonomi. Sumber-sumber tersebut adalah Al-Qur'an, Hadist, ljma', Qiyas, 'Urf, Istihsan, dan Masiahah Mursalah. Dengan demikian, dapat dikatakan bahwa pada hakikatnya ekonomi syariah adalah subsistem keilmuan yang bersumber dari sumbersumber ajaran Islam dalam hal yang menyangkut harta dan sumber daya ekonomi yang diberikan Tuhan kepada makhluk-Nya untuk meningkatkan kemakmuran umat manusia. Oleh karena itu, sesuai dengan ajaran Islam, ekonomi syariah mementingkan nilai kemakmuran, ketakwaan, peningkatan taraf kehidupan yang selaras antara material dan spiritual, pelaksanaan tanggung jawab sosial dan pelestarian lingkungan.

\section{Teori Kompetensi}

Secara umum kompetensi dapat didefinisikan sebagai sekumpulan pengetahuan, keterampilan, sikap, dan nilai sebagai kinerja yang berpengaruh terhadap peran, perbuatan, prestasi, serta pekerjaan seseorang. Dengan demikian, kompetensi dapat diukur dengan standar umum serta dapat ditingkatkan melalui pendidikan dan pelatihan (Yulaelawati, 2004:16). Kompetensi merupakan perpaduan dari pengetahuan, keterampilan, nilai dan sikap yang direfleksikan dalam kebiasaan berfikir dan bertindak (Mulyasa, 2006:37-38).

\section{Kompetensi Dasar Ekonomi Syariah}

Sebagai konsekuensi tidak terpisahkannya aktivitas ekonomi dengan nilai etika dalam dunia ekonomi, terdapat beberapa kompetensi yang perlu diperhatikan, sebagai berikut: (1) Kompetensi untuk kesadaran etika (ethical sensibility); (2) Kompetensi untuk berpikir secara etika (ethica) reasoning); (3) Kompetensi untuk bertindak secara etika (ethical conduct); dan (4) Kompetensi untuk kepemimpinan etika (ethical leadership) (Keraf, 1991:77).

Keempat kompetensi di atas merupakan tulang pungggung (backbound) watak manusia dan dapat menjadi lebih kuat jika diaplikasikan dalam kehidupan. Kompetensi kesadaran etis terlihat pada kapabilitas untuk menentukan aspek-aspek dari suatu situasi yang menuntut untuk menyadari bahwa suatu aktivitas ekonomi sesuai dengan etika atau tidak. Kesadaran ini akan muncul apabila seseorang terlebih dahulu mengetahui nilai-nilai etika. Dalam hal ini termasuk pula kemampuan untuk menerapkan etika yang umum pada situasi yang dihadapi dengan upaya peningkatan kesadaran akan pentingnya etika dalam ekonomi. Pendidikan etika dapat mengintrodusir prinsip-prinsip atau 
konsep etika yang khusus pada dunia ekonomi.

Perilaku benar yang mengandung kinerja yang baik sangat dihargai dan dianggap sebagai suatu investasi bisnis yang benar-benar menguntungkan. Karena, hal itu akan menjamin adanya kedamaian di dunia dan juga kebahagiaan di akhirat. Panduan tentang bagaimana perilaku seseorang itu benar diukur dan dinilai berdasarkan Al-Qur'an dan diselaraskan dengan perilaku Rasulullah. Allah SWT berfirman:

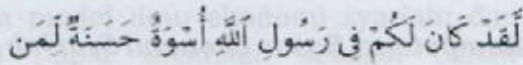

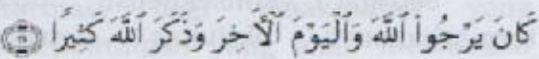

Artinya: "Sesungguhnya telah ada pada (diri) Rasulullah itu suri teladan yang baik bagimu (yaitu) bagi orang yang mengharap (rahmat) Allah dan (kedatangan) hari kiamat dan dia banyak menyebut Allah".(QS. Al-Ahzab, 33: 21).

Di samping jujur dan benar, sikap amanah sangat diperlukan dalam aktivitas ekonomi. Amanah berarti mengembalikan hak apa saja kepada pemiliknya, tidak mengambil sesuatu melebihi haknya dan tidak mengurangi hak orang lain, baik berupa harga atau upah (Al-Qardlawi, 175). Allah SWT berfirman: Allah berfirman dalam Surat An-Nisa ayat 58 :

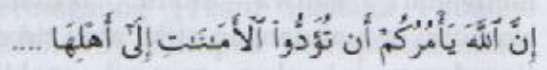

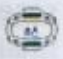

Artinya: "Sesungguhnya Allah menyuruh kamu menyampaikan amanat kepada yang berhak menerimanya". (QS.An-Nisa, 4:58).

Bisnis dengan sikap amanat dikenal dalam Islam seperti menjual dengan sistem murabahah dimana penjual menjelaskan ciri-ciri, kualitas, dan harga barang dagangan kepada pembeli tanpa melebihkannya. Amanat bertambah penting pada saat seseorang membentuk serikat dagang (musyarakah), melakukan bagi hasil (mudharabah), atau menitipkan barang untuk menjalankan proyek yang telah disepakati bersama (wa'diah). Dalam hal ini, pihak yang lain percaya dan memegang janji demi kemaslahatan bersama. Jika salah satu pihak menjalankannya hanya demi kemaslahatan dirinya sendiri, maka ia telah berkhianat.

\section{Sumber Daya Manusia Ekonomi Syariah}

Sumber Daya Manusia (SDM) yang berkualitas dan unggul merupakan salah satu diterminan yang sangat penting dalam pembangunan. Hal ini mengingat bahwa, manusia adalah penggerak dalam pembangunan yang mengantisipasi masalah, membuat perencanaan, mempertimbangkan sistem nilai agama dan masyarakat, menggali Sumber Daya Alam (SDA), mengakumulasi dana, membangun organisasi sosial, ekonomi dan politik, dan meletakkan semuanya dalam satu wadah "pembangunan" (Aziz \& Ulfah, 2010:60).

SDM yang optimal memerlukan dua jenis kualitas, yaitu professional quality dan moral quality. Professional quality mengacu kepada kualitas kemampuan dan efisiensi kerja. Seorang operator mesin tidak akan dapat bekerja secara efisien seandainya tidak mengusai teknis mesin secara profesional. Dalam waktu yang sama operator tidak mungkin bekerja secara disiplin, tepat waktu, dan berdedikasi kepada pekerjaan tampa pamrih dan menghindari segala jenis korupsi (termasuk waktu dan komisi dalam pembelian suku cadang) seandainya 
tidak memiliki moral quality. Suatu hal yang sangat disayangkan, mainstream economics and management lebih menitikberatkan kepada professional quality dan kurang memperhatikan moral quality. Akibatnya, muncullah para teknokrat yang jenius dan profesional, tetapi berhati musang, dan tidak atau kurang mengindahkan tujuan dari pembangunan yang tercemin dalam amanah dan hajat hidup masyarakat banyak (Muhammad Syafi'i Antonio 2001:353).

Secara jelas dan jitu, Islam menyambung missing link antara professional qulity dengan moral quality. $\mathrm{Hal}$ ini dilihat bahwasannya, Islam melihat bahwa manakala seorang bekerja untuk orang lain atau perusahaan ia telah memasuki sesuatu yang dipegang teguh dan tidak dapat diabaikan begitu saja. Allah SWT berfirman:

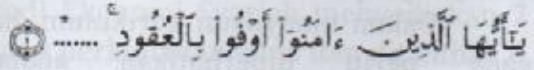

Artinya: "Hai orang-orang yang beriman, penuhilah aqad-aqad itu" [QS. A] Maaidah, 5: 1).

Dalam Surat Al-Mhutaffifiin ayat 1 dengan keras Al-Qur'an mencela mereka yang manakala menerima, ingin mendapat takaran penuh tetapi manakala memberi, ingin menguranginya. Bila kita aplikasikan ke dalam SDM tepat bagi mereka yang tidak efisien dan bermalas-malasan tetapi mereka meminta gaji dengan penuh. Allah SWT berfirman:

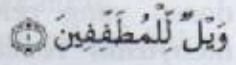

Artinya: "Kecelakaan besarlah bagi orang-orang yang curang ( yang dimaksud dengan orang-orang yang curang di sini ialah orang-orang yang curang . dalam menakar -danmenimbang)". (QS. Al-Mhutaffiffiin, 83:1).
Adapun moral quality, menunjukkan bahwa dimensi moral yang dikehendaki untuk dikuasai SDM telah jelas digariskan. Moral quality adalah mengacu pada kemampuan SDM dalam meletakkan dirinya dalam menjalankan tugas kesehariannya sesuai dengan aturan-aturan permainan yang telah digariskan oleh Allah SWT (Muhammad, 2000:10) dalam Abdul Aziz dan Mariyah Ulfah (2010:61).

Karena itu, untuk membangun kualitas SDM unggul diperlukan upayaupaya sadar untuk mentransformasikannya menuju kondisi yang lebih baik dan berdaya guna melalui pengembangan SDM yang Islami, dengan meningkatkan enam macam kekuatan, sebagai berikut: (1) Kekuatan iman (quwwatul iman); (2) Kekuatan ilmu (quwwatul ilmi); (3) Kekuatan moral (quwwatul akhlak); (4) Kekuatan semangat juang (quwwatul jihad); (5) Kekuatan ekonomi (quwwatul iqtishad); dan (6) Kekuatan kesetiakawanan (quwwatul tamasuk al-Ijtmia'iy).

B.). Habibie, sebagaimana telah disinggung di atas, menyebutkan pula bahwa SDM yang unggul sangat diperlukan dalam rangka meningkatkan minimalitas pelayanan, dan itu menjadi acuan (reference) pula dalam keberhasilan kualitas kerja. Kualitas minimum dari SDM yang diperlukan perlu didukung oleh lima kriteria, sebagai berikut: (1) Kualitas iman (quality believe); (2) Kualitas pikir (quality idea); (3) Kualitas kerja (quality work); (4) Kualitas kreasi (quality creation); dan (5) Kualitas hidup (quality live).

Lima kriteria harus dapat dicapai oleh masyarakat yang sudah menikmati hidup di atas garis kemiskinan, dan ini menurut Habibie, disebut sebagai kualitas minimum SDM. Artinya, garis minimum adalah dimensi kesatu, kualitas minimum adalah dimensi 
kedua, dan pelayanan minimum adalah dimensi ketiga.

Dalam kaitannya dengan kegiatan ekonomi, kekuatan SDM dan lima kualitas di atas, nampaknya kekuatan dan kualitas iman dan ilmu, serta amal merupakan faktor penting dan dominan. Karena hal ini dianggap katalisator dari professional quality dan moral quality yang berujung pada fungsi manusia sebagai khalifah fi al-ardhi. Dan khalifah $f i$ al-ardhi ini terwujud bila sifat-sifat ketuhanan telah mewarnai dirinya, "Jadilah kalian Rabbaniyyin" kata Allah. Artinya, sifat-sifat yang bersumber pada Al-Asma Al-Husna mampu besinergi dalam diri pribadi khalifah fii ardh, maka berdampak pada rahmatan Iil 'alamin.

\section{Dunia Kerja Lulusan Sarjana \\ Ekonomi Syariah}

Menurut Muhammad Syafi'i Antonio (2001:255), Dunia kerja adalah tempat dimana seseorang menuangkan ilmu yang diperolehnya selama di bangku perkuliahan. Dunia kerja merupakan tujuan akhir yang ingin diraih setiap lulusan. Oleh sebab itu, Fakultas Agama Islam Universitas Islam Riau khususnya Program Studi Ekonomi Syariah mempersiapkan Kompetensi Lulusan Sarjana Ekonomi Syariah sehinggga berdaya guna dengan dunia kerjanya nanti, baik di bidang industri perbankan syariah maupun lembaga keuangan syariah lainnya.

Para Lulusan Sarjana Ekonomi Syariah diharapkan tidak saja akan memiliki kemampuan ilmiah yang cukup tinggi tentang ilmu ekonomi syariah, tetapi juga diharapkan mampu mengembangkan dan mengelola dunia kerja seperti lembaga-lembaga bisnis syariah, lembaga swadaya masyarakat, dan lembaga pendidikan atau penelitian yang berkaitan dengan ekonomi syariah secara keseluruhan.
Upaya FAI UIR Prodi Ekonomi Syariah dalam Mempersiapkan Kompetensi Lulusan Sarjana Ekonomi Syariah Perencanaan Kurikulum dan Dosen

Dalam Buku Pedoman FAI UIR tahun 2013, suatu lembaga pendidikan bisa dikatakan bermutu apabila mempunyai standar kualitas, seperti input, proses dan output. Input yaitu penyusunan kurikulum, ketersediaan tenaga pendidik, yaitu dosen dan tenaga pendidikan yang terdiri dari pimpinan sampai dengan bawahan, adanya mahasiswa, sarana dan prasarana, manajemen pendidikan, serta mempunyai laporan keuangan. Proses, yaitu proses perkuliahan/akademik, dan terakhir adalah output, baik itu mahasiswa maupun alumni harus memiliki prestasi akademik yang baik dan akan lebih baik lagi jika mereka mempunyai prestasi luar akademik.

Dalam menyusun kurikulum, hal yang perlu diperhatikan adalah melibatkan pihak-pihak yang memang bergerak di bidang ekonomi syariah, seperti Masyarakat Ekonomi Syariah (MES), begitu pula dalam merevisi kurikulum, perlu mengadakan workshop yang juga melibatkan pihakpihak yang bergerak di bidang ekonomi syariah, agar kurikulum yang disusun nantinya bermafaat dan berdaya guna dengan dunia kerja para lulusan.

FAI UIR Prodi Ekonomi Syariah menyusun kurikulum dan menyediakan tenaga pengajar, yaitu dosen. Penyusunan kurikulum, ketersediaan dosen yang relevan dengan jurusan, menyusun rencana strategi dan visi, misi serta tujuan ekonomi syariah, ini merupakan persyaratan utama dalam menciptakan Lulusan Sarjana Ekonomi Syariah dengan kompetensi yang dicari oleh lembaga-lembaga yang disebutkan di atas. 


\section{Sarana dan Prasarana}

Ketersediaan ruang dan segala fasilitas yang dimiliki oleh FAI UIR sangat berkaitan dengan proses perkuliahan mahasiswa ekonomi syariah. Tanpa dukungan sarana dan prasarana proses belajar mengajar perkuliahan tidak akan terlaksana. Sarana adalah segala sesuatu yang dapat dipakai baik berupa alat atau media (Team Pustaka Phoenix, 2008:762). Sedangkan prasarana adalah segala sesuatu yang menunjang proses perkuliahan tersebut (Peter Salim dan Yenny, 2002:1188).

Oleh sebab itu, agar aktivitas perkuliahan dapat berjalan dengan baik dan lancar, dibutuhkan sarana dan prasarana yang representatif. Sarana yang paling terpenting adalah ruang perkuliahan. Tanpa ruang perkuliahan proses belajar mengajar tidak akan berlangsung. Dalam hal ini, FAI UIR Prodi Ekonomi Syariah menyediakan 7 ruang perkuliahan lama dan ditambah 8 ruang perkuliahan baru yang masingmasing ruangan tersebut dilengkapi dengan infokus. Proses perkuliahan mahasiswa ekonomi syariah tentunya perlu didukung dengan labor komputer ekonomi syariah. Selain itu, FAI UIR Prodi Ekonomi Syariah menyediakan ruangan dosen, ruangan untuk Ketua Jurusan, Staf Tata Usaha, Dekan, Wakil Dekan I, Wakil Dekan II, Wakil Dekan III. ruang rapat, aula, ruang sidang untuk skripsi, perpustakaan dengan jumlah buku sebanyak 1500 buku, Badan Ekskutif Mahasiswa (BEM), Dewan Mahasiswa (DEMA), dan kantin.

Selain itu, UIR juga menyediakan prasarana yang berkaitan dengan kegiatan ekonomi, yaitu Bank Unistrama, Bank Kas Syariah Mandiri, fasilitas Aoutomatic Teller Mesin (ATM Bank Syariah Mandiri, Bukopin, dan Bank Muamalat), serta fasilitas pendukung lainnya, seperti perpustakaan UIR, laboratorium komputer (BAIT), fasilitas WIFI, masjid dan lapangan bola. Tanpa sarana dan prasarana yang disebutkan di atas mungkin Lulusan Sarjana Ekonomi Syariah yang unggul tidak dapat tercipta karena sarana dan prasarana merupakan salah satu faktor penting dalam menciptakan Lulusan Sarjana Ekonomi Syariah.

\section{METODE PENELITIAN}

Penelitian ini dilakukan di Fakultas Agama Islam Universitas Islam Riau, khususnya Program Studi Ekonomi Syariah Jalan Kaharuddin Nasution Km. 11 No.113 Perhentian Marpoyan Pekanbaru, dan dimulai dari bulan Januari s/d April 2013, yaitu selama empat bulan, dengan perencanaan sebagai berikut:

Dalam penelitian ini yang dijadikan populasi adalah seluruh Lulusan Sarjana Ekonomi Syariah Fakultas Agama Islam Universitas Islam Riau sebanyak 61 lulusan.

Dalam penelitian ini metode pengumpulan data yang digunakan adalah: (a) Angket (questionier), yaitu menyebarkan daftar pernyataan guna mempermudah di dalam pelaksanaan pengumpulan data. Pernyataan yang dirancang untuk mengukur variabel bebas, yaitu kompetensi Lulusan Sarjana Ekonomi Syariah dan variabel terikat, yaitu dunia kerja. Pengukuran variabel dilakukan dengan menggunakan skala tiga alternatif pilihan (Hadari Nawawi dan Martini Hadari, 2006:123); (b) Wawancara (interview), yaitu penulis menanyakan langsung kepada Ketua Jurusan Ekonomi Syariah guna memperoleh informasi yang berkaitan dengan Studi Ekonomi Syariah; dan (c) Dokumentasi (Documentation), yaitu penulis akan menyimpulkan dari bahan-bahan dokumen Fakultas Agama Islam Universitas Islam Riau, khususnya 
Program Studi Ekonomi Syariah yang berhubungan dengan masalah yang akan diteliti.

\section{HASIL}

Gambaran Umum Lokasi Penelitian Sejarah Singkat Fakultas Agama IsIam Universitas Islam Riau

Sebelum berubah nama menjadi Fakultas Agama Islam (FAI), Fakultas ini bernama Fakultas Ushuluddin. Fakultas ini merupakan Fakultas tertua dan satusatunya Fakultas Agama diantara tujuh Fakultas yang ada di lingkungan Universitas Islam Riau (UIR). Fakultas ini didirikan pada tanggal 17 Mei 1963.

\section{Visi, Misi dan Tujuan Fakultas Agama} Islam (FAI) Universitas Islam Riau (UIR)

Adapun visi fakultas agama Islam Universitas Islam Riau adalah menjadi Pusat keunggulan studi ilmu-ilmu keislaman dan pengembangan sumber daya manusia di Provinsi Riau tahun 2020

Misi dari fakultas agama Islam Universitas Islam Riau adalah: (a) Membentuk Sarjana Ilmu Agama Islam yang mengusai bidang ilmu secara profesional; (b) Menyiapkan sumber daya manusia yang terampil, kreatif, responsif dan inovatif; dan (c) Membentuk Sarjana Ilmu Agama Islam yang hafidz, amanah dan istiqomah.

Tujuan fakultas agama Islam Universitas Islam Riau adalah: (a) Melahirkan Sarjana Agama yang beriman dan bertaqwa; (b) Melahirkan Sarjana Agama yang mengusai bidang ilmu secara profesional; dan (c) Melahirkan Sarjana Agama yang terampil, kreatif, mandiri, dan amanah.
Visi dan Misi Jurusan Ekonomi Syariah FAI UIR

Adapun visi dari jurusan ekonomi syariah FAI UIR adalah menjadi Pusat keunggulan studi ekonomi syariah dan pengembangan sumber daya manusia di Provinsi Riau tahun 2020.

Sedangkan misi jurusan ekonomi syariah FAI UIR adalah (a) Mengembangkan dan menyiapkan lulusan yang kompeten dan profesional, memberdayakan sumber daya ekonomi syariah sesuai dengan perkembangan ilmu pengetahuan teknologi dan serta kebutuhan pembangunan nasional maupun daerab; (b) Memberi kebebasan dan kesempatan pengemban sistem ekonomi syariah yang berazaskan akhlak mulia dan nilai-nila Islam; (c) Mengembangkan dan meningkatkan peran serta sekolah tinggi ekonomi syariah melalui optimalisasi tridharma perguruan tinggi yang terdiri dari pendidikan, penelitian dan pengabdian pada masyarakat baik dalam pengembangan daerah maupun nasional; dan (d) Membentuk generasi muda Islam yang mampu mandiri melalui kewirausahaan yang berpegan teguh kepada syariat agama Islam. Selanjutnya, tujuan jurusar ekonomi syariah FAI UIR adalah : (a) Untuk menghasilkan manusia yang beriman dan bertaqwa, berbudi pekerti luhur, berkepribadian mandiri, cerdas, kreatif, trampil berdisiplin, bertanggung jawab mempunyai etos kerja, produktif, dan berguna bagi agama dan negara; (b) Untuk menciptakan generasi muda Islam yang bisa mengusai ilmu ekonomi Islam dan menciptakan inovasi-inovasi yang cemerlang, dalam rangka menjadikan ekonomi Islam sebagai ekonomi dunia; dan (c) Untuk menciptakan dan menghasilkan wirausahaan-wirausahaan muslim yang berpegang teguh pada syariat dan berakhlak mulia. 


\section{Gambar 1 \\ Struktur Organisasi FAI UIR}

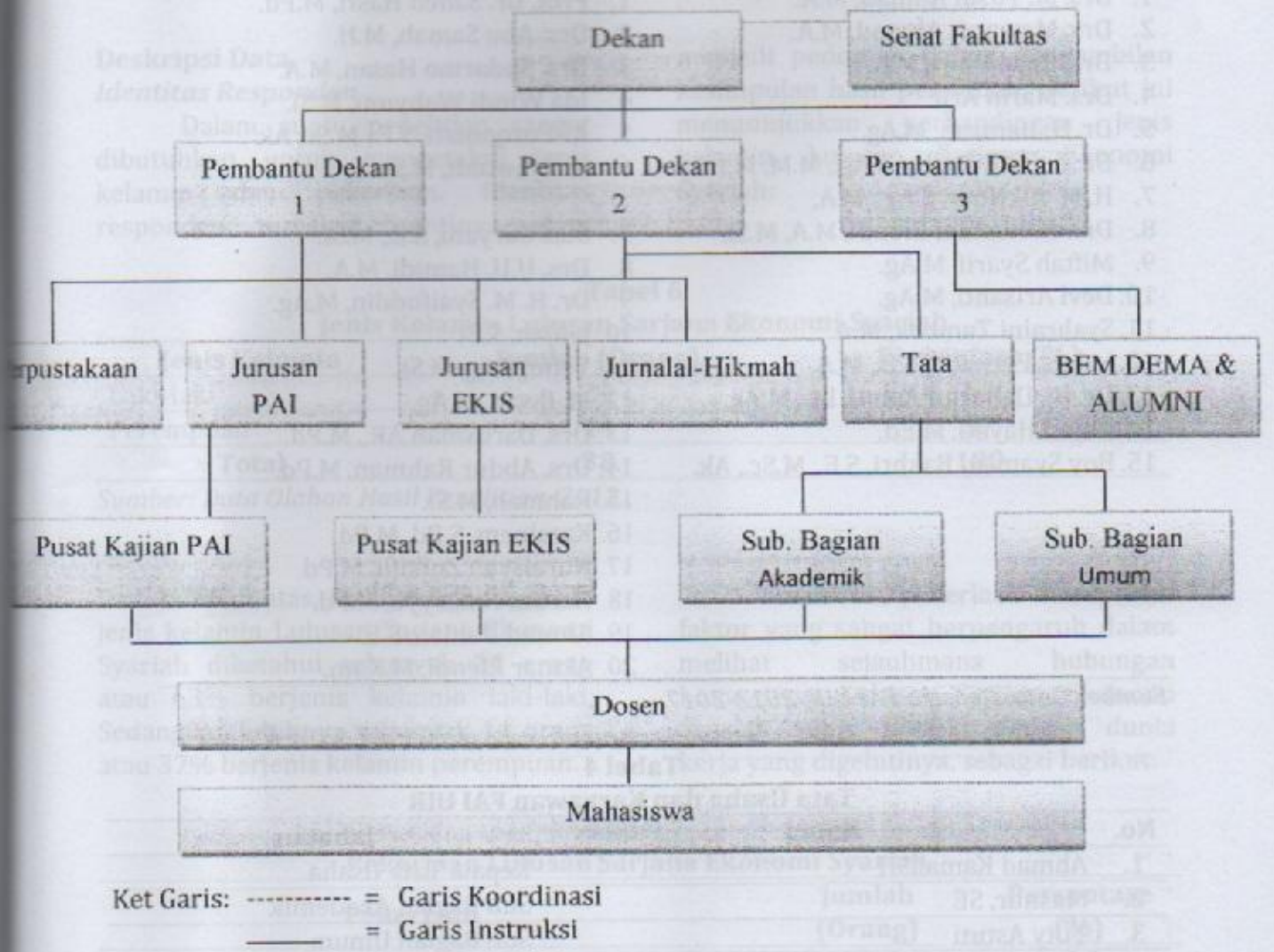

Tabel 2

Pimpinan FAI UIR

\begin{tabular}{cll}
\hline No. & \multicolumn{1}{c}{ Nama } & \multicolumn{1}{c}{ Jabatan } \\
\hline 1. & Drs. M. Yusuf Ahmad, M.A. & Dekan \\
\hline 2. & Dr. Zulkifli Rusby, S.Ag., M.M. M.E.Sy. & Wakil Dekan I \\
\hline 3. & Drs. Rizal Dairi, M.A. & Wakil Dekan II \\
\hline 4. & Drs. Mawardi Ahmad, M.A. & Wakil Dekan III \\
\hline 5. & Miftah Syarif, M.Ag. & Ketua Jurusan Pendidikan Agama Islam \\
\hline 6. & Syahraini Tambak, M.A. & Sekretaris Jurusan \\
\hline 7. & Lolyta Permata, S.E., M.A. & Ketua Jurusan Ekonomi Syariah \\
\hline 8. & Boy Syamsul Bakhri, S.E., M.Sc., Ak. & Sekretaris Jurusan \\
\hline
\end{tabular}

Sumber Data: Renstra FAI UIR, 2012-2017. 
Tabel 3

Dosen Tetap dan Dosen Luar Biasa FAI UIR

\begin{tabular}{l}
\multicolumn{1}{c}{ Dosen Tetap } \\
\hline 1. Drs. M. Yusuf Ahmad, M.A. \\
2. Drs. Mawardi Ahmad, M.A. \\
3. Drs. Rizal Dairi, M.A. \\
4. Drs. Marin Arif \\
5. Dr. H. Hamzah, M.Ag. \\
6. Dr. Zulkifli Rusby, S.Ag., M.M. M.E.Sy. \\
7. H. M. Ali Noer, S.Ag., M.A. \\
8. Drs. H. Rustam Efendi, M.A, M.Si. \\
9. Miftah Syarif, M.Ag. \\
10. Devi Arisanti, M.Ag. \\
11. Syahraini Tambak, M.A. \\
12. Lolyta Permata, S.E., M.A. \\
13. Dr. Hj. Daharmi Astuti, Lc., M.Ag. \\
14. Najmi Hayati, M.Ed. \\
15. Boy Syamsul Bakhri, S.E., M.Sc., Ak.
\end{tabular}

Dosen Luar Biasa

1. Prof. Dr. Salfen Hasri, M.Pd.

2. Drs. Abu Samah, M.H.

3. Drs. Sudarmo Hasan, M.A.

4. Ida Windi Wahyuni, M.Si.

5. Al-Furqoniati, S.E., M.Si., Ak.

6. Ir. Syawaldi, M.Sc.

7. Susi Suryani, S.E., M.Si.

8. Drs. U.U. Hamidi, M.A.

9. Dr. H. M.Syaifuddin, M.Ag.

10. Jalijah, S.Ei

11. Yefni, S.Ag, M.Si.

12. M. Ihsan, M.Ag.

13. Drs. Darusman AR., M.Pd.

14. Drs. Abdur Rahman. M.Pd.

15. Rahmah, M.Si.

16. Karsinem, S.Pd, M.Pd.

17. Nuraisyah Zulkifli, M.Pd.

18. Harum Natasyya, M.Pd.

19. Ahmad Dahlan, S.E.

20. Akmar Efendi, M.Kom.

Sumber Data: Renstra FAI UIR, 2012-2017.

Tabel 4

Tata Usaha dan Karyawan FAI UIR

\begin{tabular}{cll}
\hline No. & \multicolumn{1}{c}{ Nama } & \multicolumn{1}{c}{ Jabatan } \\
\hline 1. & Ahmad Kamal,SH & Kepala Tata Usaha \\
\hline 2. & Masnur, SE & Sub Bagian Akademik \\
\hline 3. & Tuty Astuti & Sub Bagian Umum \\
\hline 4. & Rasyid & Karyawan \\
& $\begin{array}{l}\text { Syawaluddin, S.Pdi, } \\
\text { Sarimah }\end{array}$ & \\
\hline
\end{tabular}

Sumber Data: Renstra FAI UIR, 2012-2017.

Tabel 5

Susunan Senat FAI UIR

\begin{tabular}{clll}
\hline No. & \multicolumn{1}{c}{ Nama } & \multicolumn{1}{c}{ Jabatan } & \multicolumn{1}{c}{ Keterangan } \\
\hline 1. & Drs. M. Yusuf Ahmad, M.A. & Ketua & Dekan \\
\hline 2. & Drs. Rizal Dairi, M.A. & Sekretaris & Wakil Dekan II \\
\hline 3. & Dr. H. Hamzah. M.Ag. & Anggota & Wakil dari PAI \\
\hline 4. & Dŕ. Zulkifli Rusby, S.Ag., M.M.M.E.Sy. & Anggota & Wakil Dekan I \\
\hline 5. & Drs. H. M. Ali Noer, M.A. & Anggota & Wakil dari Ekis \\
\hline
\end{tabular}




\begin{tabular}{llll}
\hline 6. & Drs. Mawardi Ahmad, M.A. & Anggota & Wakil Dekan III \\
\hline 7. & Miftah Syarif, M.Ag. & Anggota & $\begin{array}{l}\text { Ketua Jurusan } \\
\text { PAI }\end{array}$ \\
\hline 8. & Drs. H. Rustam Efendi, M.A, M.Si. & Anggota & Wakil dari Ekis \\
\hline
\end{tabular}

Sumber Data: Renstra FAI UIR, 2012-2017.

\section{Deskripsi Data}

Identitas Responden

Dalam suatu penelitian sangat dibutuhkan untuk mengetahui jenis kelamin dan pekerjaan. Identitas responden tersebut nantinya akan menjadi pedoman dalam pengambilan kesimpulan hasil penelitian. Berikut ini menunujukkan perbandingan jenis kelamin Lulusan Sarjana Ekonomi Syariah:

Tabel 6

Jenis Kelamin Lulusan Sarjana Ekonomi Syariah

\begin{tabular}{lcc}
\hline \multicolumn{1}{c}{ Jenis Kelamin } & Jumlah (Orang) & Persentase (\%) \\
\hline Laki-laki & 24 & 63 \\
\hline Perempuan & 14 & 37 \\
\hline \multicolumn{1}{c}{ Total } & 38 & 100 \\
\hline
\end{tabular}

Sumber: Data Olahan Hasil Penelitian, 2013.

Dari tabel di atas, terlihat bahwa untuk jenis kelamin Lulusan Sarjana Ekonomi Syariah diketahui sebanyak 24 orang atau $63 \%$ berjenis kelamin laki-laki, Sedangkan lebihnya sebanyak 14 orang atau $37 \%$ berjenis kelamin perempuan.
Selain itu, pekerjaan merupakan faktor yang sangat berpengaruh dalam melihat sejauhmana hubungan kompetensi Lulusan Sarjana Ekonomi Syariah yang dimiliki dengan dunia kerja yang digelutinya, sebagai berikut:

Tabel 7

Pekerjaan Lulusan Sarjana Ekonomi Syariah

\begin{tabular}{|c|c|c|}
\hline Pekerjaan & $\begin{array}{l}\text { Jumlah } \\
\text { (Orang) }\end{array}$ & $\begin{array}{c}\text { Persentase } \\
(\%)\end{array}$ \\
\hline Lembaga Keuangan Syariah & 9 & 24 \\
\hline Lembaga Keuangan Non Syariah & 6 & 16 \\
\hline Instansi Pemerintahan, PT, CV, Perusahaan Swasta & 7 & 18 \\
\hline Lembaga Pendidikan & 10 & 26 \\
\hline Lembaga Sosial & 2 & 5 \\
\hline Wirausahaan & 4 & 11 \\
\hline$x^{2}$ & 38 & 100 \\
\hline
\end{tabular}

Sumber: Data Olahan Hasil Penelitian, 2013.

Dari tabel di atas, terlihat bahwa untuk pekerjaan Lulusan Sarjana Ekonomi Syariah diketahui sebanyak 9 orang atau $24 \%$ yang bekerja di lembaga keuangan syariah, 6 orang atau $16 \%$ yang bekerja di lembaga keuangan non syariah, 7 orang atau $18 \%$ yang bekerja di instansi pemerintahan, PT, CV, dan-Perusahaan Swasta, 10 orang atau $26 \%$ yang bekerja di lembaga pendidikan, 2 orang atau $5 \%$ 
yang bekerja di lembaga sosial, dan selebihnya 4 orang atau $11 \%$ yang bekerja sebagai wirausahaan.

Berdasarkan deskripsi di atas, dapat disimpulkan bahwa sebesar $40 \%$ dari 38 Lulusan Sarjana Ekonomi Syariah yang diteliti, sudah bekerja sesuai dengan jurusan, yaitu bekerja di lembaga keuangan syariah, lembaga sosial, dan menjadi wirausahaan.

Dari tabel di atas, dapat diketahui sebanyak 30 orang atau $79 \%$ responden menyatakan setuju mampu bekerjasama secara tim dalam dunia kerja, dan selebihnya sebanyak 8 orang atau $21 \%$ responden menyatakan raguragu mampu bekerjasama secara tim dalam dunia kerja.
Berdasarkan deskripsi di atas, dapat disimpulkan bahwa sebesar $79 \%$ dari 38 lulusan yang diteliti, hampir semua lulusan mampu bekerjasana secara tim dalam dunia kerja.

\section{Uji Validitas dan Reabilitas \\ Instrumen Penelitian}

Melalui pengolahan data menggunakan sistem komputerisast yaitu dengan memanfaatkan Statistik SPSS (Statistics Pro Service Solutions) versi 17. diperoleh hasil perbandingan uj. validitas masing-mașing item variabel penelitian yaitu variabel $\mathrm{X}$ dan variabel Y sebagai berikut (hasil pengujian terlampir):

Tabel 8

Hasil Uji Validitas Instrumen Penelitian

\begin{tabular}{|c|c|c|c|c|}
\hline Variabel & $\begin{array}{c}\text { Item } \\
\text { Pernyataan }\end{array}$ & $\begin{array}{l}\text { Corrected Item } \\
\text { Total Colleration } \\
\text { ( } \mathrm{r} \text { hitung) }\end{array}$ & $\begin{array}{c}r \text { tabel } \\
\alpha=0,05\end{array}$ & $\begin{array}{c}\text { Keterangan } \\
\text { Hasil }\end{array}$ \\
\hline $\mathrm{X}$ & 1 & 0,502 & 0,320 & Valid \\
\hline 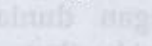 & 2 & 0,750 & 0,320 & Vatid \\
\hline & 3 & 0,806 & 0,320 & Valid \\
\hline & 4 & 0,750 & 0,320 & Valid \\
\hline nive & 5 & 0,750 & 0,320 & Valid \\
\hline 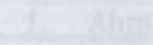 & thes & 0,795 & 0,320 & Valid \\
\hline 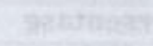 & fistint & 0,794 & 0,320 & Valid \\
\hline & lats & 0,488 & 0,320 & Valid \\
\hline 85 & 9 & 0,795 & 0,320 & Valid \\
\hline erf & 10 & 0,699 & 0,320 & Valid \\
\hline Plis: & 11 & 0,556 & 0,320 & Valid \\
\hline & 12 & 0,518 & 0,320 & Valid \\
\hline 2 & 13 & 0,795 & 0,320 & Valid \\
\hline 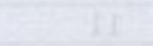 & 14 & 0,795 & 0,320 & Valid \\
\hline +8018 & 15 & 0,559 & 0,320 & Valid \\
\hline $\mathrm{Y}$ & 1 & 0,765 & 0,320 & Valid \\
\hline & 2 & 0,756 & 0,320 & Valid \\
\hline & 3 & 0,756 & 0,320 & Valid \\
\hline 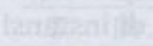 & 4 & 0,756 & 0,320 & Valid \\
\hline 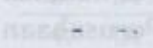 & 5 & 0,590 & 0,320 & Valid \\
\hline 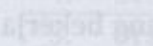 & 6 & 0,756 & 0,320 & Valid \\
\hline & 7 & 0,756 & 0,320 & Valid \\
\hline
\end{tabular}




\begin{tabular}{cccc}
8 & 0,756 & 0,320 & Valid \\
9 & 0,756 & 0,320 & Valid \\
10 & 0,665 & 0,320 & Valid \\
11 & 0,488 & 0,320 & Valid \\
12 & 0,756 & 0,320 & Valid \\
13 & 0,756 & 0,320 & Valid \\
14 & 0,569 & 0,320 & Valid \\
15 & 0,661 & 0,320 & Valid \\
\hline
\end{tabular}

Sumber: Data Olahan SPSS 17.0,2013.

Instrumen dikatakan valid jika Corrected Item Total Correlaction ( $r$ hitung) menunjukkan korelasi yang signifikan antara skor item dengan nilai tabel ( $r$ tabel). Jika rintung $>$ rabel maka instrumen dikatakan valid. Dari tabel di atas maka terlihat bahwa semua instrumen item variabel adalah valid.

Selanjutnya, untuk mengetahui hasil uji reliabilitas maka digunakan sistem pengolahan data SPSS versi 17.0, yaitu sebagai berikut (hasil pengujian terlampir):

Tabel 9

Hasil Uji Reliabilitas Instrumen Penelitian

\begin{tabular}{ccc}
\hline Variabel & Guttman Split-Half Coefficient & Keterangan Hasil \\
\hline $\mathrm{X}$ & 0,854 & Reliabel \\
\hline $\mathrm{Y}$ & 0,829 & Reliabel
\end{tabular}

Sumber: Data Olahan SPSS 17.0, 2013.

Berdasarkan tabel di atas, maka dalam hal ini dapat dikatakan instrumen variabel dari penelitian adalah baik karena nilai koefisien Guttman SplitHalf yang diperoleh kehandalannya di atas 0,8 .

Setelah dilakukan pengujian uji validitas dengan menggunakan rumus Korelasi Product Moment dan uji reliabilitas menggunakan Guttman SplitHalf di atas dapat disimpulkan bahwa 30 butir pernyataan atau tanggapan responden mengenai hubungan kompetensi Lulusan Sarjana Ekonomi
Syariah dengan dunia kerja dinyatakan valid dan reliabel.

\section{Analisis Korelasi Spearman Rank}

Analisis korelasi digunakan untuk mengukur keeratan hubungan antara dua variabel. Korelasi ini tidak mensyaratkan distribusi normal dan bisa memakai data tipe ordinal. Melalui pengolahan data menggunakan program SPSS versi 17.0, maka diperoleh hasil Koefisien Korelasi Spearman Rank dan diterminan sebagai berikut:

Tabel 10

Analisis Koefisien Korelasi Spearman Rank

\begin{tabular}{|c|c|c|c|c|}
\hline & & & $\begin{array}{l}\text { Kompetensi } \\
\text { Lulusan SESy }\end{array}$ & Dunia Kerja \\
\hline \multirow{4}{*}{$\begin{array}{l}\text { Spearman's } \\
\text { rho }\end{array}$} & \multirow{3}{*}{$\begin{array}{l}\text { Kompetensi } \\
\text { Lulusan } \\
\text { S.E.Sy. }\end{array}$} & Correlation Coefficient & 1.000 & $.732^{* *}$ \\
\hline & & Sig. (2-tailed) & $\cdot$ & .000 \\
\hline & & $\mathrm{N}+\ldots$ & 38 & 38 \\
\hline & Dunia Kerja & Correlation Coefficient & $.732^{*}$ & 1.000 \\
\hline
\end{tabular}




\begin{tabular}{lrrr}
\hline Sig. (2-tailed) & .000 & \\
\cline { 2 - 4 } $\mathrm{N}$ &
\end{tabular}

Sumber: Data Olahan Hasil Penelitian, 2013.

Berdasarkan tabel di atas maka dapat dijelaskan bahwa ada hubungan yang signifikan antara kompetensi Lulusan Sarjana Ekonomi Syariah dengan dunia kerja sebesar 0,732 dan berdasarkan tabel interpretasi koefisien korelasi nilai rho's maka tingkat hubungannya dalam kategori "kuat" karena nilai korelasi berada dalam interval $0,60-0,799$. Sedangkan arah hubungan adalah positif karena nilai $r$ positif, berarti semakin berkualitas kompetensi yang dimiliki Lulusan Sarjana Ekonomi Syariah maka semakin bermanfaat (berdaya guna) dengan dunia kerja yang mereka geluti.

Selanjutnya dari tabel di atas, dapat diketahui besar kecilnya sumbangan variabel $X$ terhadap variabel $Y$ dengan menggunakan rumus diterminan sebagai berikut:

$\mathrm{KP}=\mathrm{r}^{2} \times 100 \%$

$=0,732^{2} \times 100 \%$

$=0,536 \times 100 \%$

$=53,60 \%$

Dalam hal ini dapat diartikan bahwa dunia kerja Lulusan Sarjana Ekonomi Syariah dipengaruhi oleh kompetensi yang dimiliki (yang diperoleh selama bangku perkuliahan), yaitu sebesar $53,60 \%$, sedangkan $46,40 \%$ dipengaruhi oleh faktor lainnya yang tidak diungkap dalam penelitian ini.

\section{Pengujian Hipotesis}

Uji signifikansi (uji t) digunakan untuk mengetahui apakah hubungan yang terjadi itu dapat berlaku untuk populasi (dapat digeneralisasikan) atau tidak, Untuk pengambil keputusan atau kriteria uji signifikansi adālah jika thitung $>t_{\text {tabel }}$ maka $\mathrm{H}_{0}$ ditolak berarti signifikan dan sebaliknya jika thitung $<t_{\text {tabel }}$ maka
$\mathrm{H}_{\mathrm{o}}$ diterima berarti tidak signifikan. Uji signifikan ini digunakan untuk menguji hipotesis penelitian, yaitu dengan rumus sebagai berikut:

$$
\begin{aligned}
I_{0} & =r_{s} \sqrt{\frac{n-2}{1-r_{a}^{2}}} \\
t_{0} & =0,732 \sqrt{\frac{38-2}{1-0,732^{2}}} \\
& =6,448
\end{aligned}
$$

Jadi, dengan demikian dapat diketahui bahwa nilai $t$ hitung sebesar 6,448 dan nilai tabel sebesar 2,028 dengan derajat kebebasan (df) $n-2$ atan $38-2=36$. Dengan pengujian dua sisi (signifikansi $=0,05$ ) hasil diperoleh untuk $t$ tabel sebesar 2,028. Nilai i hitung $>t$ tabel $(6,448>2,028)$ maka $h$. ditolak, artinya bahwa ada hubungar. yang signifikan antara kompetensi Lulusan Sarjana Ekonomi Syariah dengan dunia kerja. Karena $t$ hitung nilainya positif, maka kompetensi Lulusan Sarjana Ekonomi Syariah berhubungan positif dan signifikan dengan dunia kerja.

\section{Hubungan Kompetensi Lulusan Sarjana Ekonomi Syariah FAI UIR dengan Dunia Kerja}

Berdasarkan hasil penelitian, diketahui bahwa walaupun Lulusan Sarjana Ekonomi Syariah ada yang bekerja sesuai jurusan sebesar $50 \%$, dan sebesar $21 \%$ Lulusan Sarjana Ekonomi Syariah ada yang tidak bekerja sesuai dengan jurusan, sedangkan lebihnya sebesar $29 \%$, keahlian/jurusan lulusan hanya berkaitan dengan bidang pekerjaannya saja (tidak untuk dunia kerja lulusan).

Namun, hubungan antara kompetensi Lulusan Sarjana Ekonom 
Syariah dengan dunia kerja saling mempunyai keterkaitan satu sama lain, dengan bekal kompetensi yang diperolehnya selama bangku perkuliahan dapat diterapkan dan mendukung pekerjaan mereka dalam dunia kerja, seperti skill atau mampu dalam menyelesaikan tugas (tanggung jawab), mampu dalam mengaplikasikan komputer (teknologi informasi), memiliki sikap profesional dalam bekerja, mampu dalam beradaptasi baik dengan lingkungan kerja maupun dengan tugas (tanggung jawab), mengusai dasar-dasar akuntansi, perbankan syariah, dan manajemen syariah, mampu menjalani kegiatan ekonomi sesuai dengan ajaran islam, mampu mengembangkan ide-ide kreatif dan inovatif, mampu berkomunikasi secara efektif dan efisien dengan siapapun, mampu membuat keputusan dan belajar dari setiap kejadian, dan memiliki rasa kepercayaan diri serta etos kerja.

Analisis akhir yang dapat disimpulkan, yaitu pertama: hubungan kompetensi lulusan sarjana ekonomi syariah dengan dunia kerja menunjukkan hubungan yang positif dan signifikan, dimana melalui hasil uji signifikansi atau uji $\mathrm{t}$ diketahui thitung sebesar 6,448 ternyata lebih besar dibandingkan dengan tabel sebesar 2,028 . Adapun nilai hubungannya atau Koefisien Korelasi Spearman Rank sebesar 0,732 dengan tingkat hubungan "kuat". Sedangkan pengaruh hubungan antara kompetensi Lulusan Sarjana Ekonomi Syariah dengan dunia kerja sebesar $53,60 \%$ dan sebesar $46,40 \%$ dipengaruhi oleh faktor lainnya. Kedua: Upaya yang dilakukan oleh Fakultas Agama Islam Universitas Islam Riau Program Studi Ekonomi Syariah dalam mempersiapkan kompetensi Lulusan Sarjana Ekonomi Syariah antara lain menyusun kurikulum yang sesuai dengan permintaan dunia kerja khususnya lembaga keuangan syariah dan lembaga-lembaga keuangan lainnya, menyediakan dosen yang relevan dengan jurusan, menyusun rencana strategi, serta menyediakan sarana dan prasarana ternyata terbukti bermanfaat dan berdaya guna bagi kompetensi Lulusan Sarjana Ekonomi Syariah itu sendiri dalam dunia kerja.

\section{SIMPULAN}

Berdasarkan hasil penelitian dan pembahasan yang telah dipaparkan di atas, maka dapatlah ditarik kesimpulan dari penelitian ini yaitu sebagai berikut: (1) Hubungan kompetensi Lulusan Sarjana Ekonomi Syariah dengan dunia kerja menunjukkan hubungan yang positif dan signifikan, hal ini terbukti dari hasil penelitian, dimana melalui hasil uji signifikansi atau uji $t$ diketahui thitung, sebesar 6,448 ternyata lebih besar dibandingkan dengan tabel sebesar 2,028 . Adapun nilai hubungannya atau Koefisien Korelasi Spearman Rank sebesar 0,732 dengan tingkat hubungan "kuat". Sedangkan pengaruh hubungan antara kompetensi Lulusan Sarjana Ekonomi Syariah dengan dunia kerja sebesar $53,60 \%$ dan sebesar $46,40 \%$ dipengaruhi oleh faktor lainnya; dan (2) Upaya yang dilakukan oleh Fakultas Agama Islam Universitas Islam Riaudalam mempersiapkan kompetensi Lulusan Sarjana Ekonomi Syariah antara lain menyusun kurikulum sesuai dengan tuntutan dunia kerja, menyediakan dosen yang relevan dengan jurusan, menyusun rencana strategi, serta upaya pendukung lainnya seperti menyediakan sarana dan prasarana ternyata terbukti bermanfaat dan berdaya guna bagi kompetensi Lulusan Sarjana Ekonomi Syariah itu sendiri dalam dunia kerja. 


\section{DAFTAR RUJUKAN}

Ali, Zainudin. 2010. Hukum Perbankan Syariah Cetakan kedua (Edisi Pertama). Jakarta: Sinar Grafika.

Antonio, Muhammad Syafi'i. 2001. Bank Syariah Dari Teari Ke Praktik Cetakan Pertama. Jakarta: Gema Insani.

Awirya, Agni Alam dan Piliyanti, Indah. Menakar Kesiapan Mahasiswa Ekonomi Syariah Menghadapi Pasar Tenaga Kerja. Journal of Islamic and Economic. Volume 2, No. 1, Juni 2008.

Aziz, Abdul dan Ulfah, Mariya. 2010. Kapita Selekta Ekonomi Islam Kontemporer. Bandung: Alfabeta.

Dairi, Rizal. 2010. Metodologi Penelitian Berbasis Kompetensi. Pekanbaru: UIR Press.

Departemen Agama RI. 2004. Al-Qur'an Dan Terjemahannya. Semarang: PT. Karya Toha.

Fauroni, Lukman. 2006. Arah Dan Strategi Ekonomi Islam Cetakan Pertama. Yogyakarta: Magistra Insania Press.

Hasan, M. Iqbal. 2010. Pokok-Pokok Materi Statistik 2 (Statistik Inferensif) Edisi Kedua Cetakan Keenam. Jakarta: Bumi Aksara.

Idri dan Tutik, Titik Triwulan. 2008. Prinsip-Prinsip Ekonomi Islam. Jakarta: Lintas Pustaka.

Martha, Fajar Luhur. 2007. "Kesiapan Mahasiswa Menghadapi Pasar Tenaga Kerja Di Bidang Ekonomi Syariah Sebagai Respon Atas Perkembangan Praktik Ekonomi Syariah Di Indonesia (Studi Kasus Sekolah Tinggi Ekonomi Syariah)", Jakarta.

Mujahidin, Akhmad. 2010. Ekonomi Islam 2. Pekanbaru: Al-Mujtahadah Press.

Muhamad. 2008. Metodologi Penelitian Ekonomi Islam Edisi Pertama. Jakarta: Rajawali Pers.
Mulyasa. 2010. Kurikulum Berbasis Kompetensi (Konsep, Karakteristik, dan Implementasi. Bandung: PT. Remaja Rosdakarya.

Naqvi, Syed Nawab Haider. 2003. Menggagas Ilimu Ekonomi Islam Cetakan Pertama. Yogyakarta: Pustaka Pelajar.

Nawawi, Hadari dan Hadari, Martini. 2006. Instrumen Penelitian Bidang Sosial. Yogyakarta: Gadjah Mada University Press.

Nawawi, Ismail. 2009. Ekonomi Islam (Perspektif Teori, Sistem Dan Aspek Hukum). Surabaya: CV. Putra Media Nusantara.

Nugroho, Yohanes Anton. 2011. It's Easy Olah Data dengan SPSS Cetakan Pertama. Yogyakarta: Skripta Media Creative.

Riduwan. 2008. Dasar-Dasar Statistika Cetakan Keenam. Bandung: Alpabeta.

Riduwan dan Sunarto. 2011. Pengantar Statistika Untuk Penelitian Pendidikan, Sosial, Ekonomi, Komunikasi, Dan Bisnis. Cetakan Keempat. Bandung: Alpabeta.

Rodoni, Ahmad dan Hamid, Abdul. 2008. Lembaga Keuangan Syariah. Jakarta: Zikrul Hakim.

Salim, Peter dan Yenny. 2002. Kamus Bahasa Indonesia Kontemporer Edisi Ketiga. Jakarta: Modern English Pers.

Sugiyono. 2012. Statistika Untuk Penelitian Cetakan Ke-20. Bandung: Alpabeta.

Team Pustaka Phoenix. 2008. Kamus Besar Bahasa Indonesia Cetakan Ketiga (Revisi). Jakarta: PT. Media Pustaka Phoenix.

Usman, A. Rani. 2001. Kampus Sebagai Institusi Pencerahan. NAD: Fakultas Dakwah IAIN Ar-Raniry.

Priyatno, Duwi. 2009. 5 Jam Belajar Olah Data dengan SPSS 17. Yogyakarta: Percetakan Andi. 
Priyatno, Duwi. 2010. Rathar Analise Statistik Dato Deroan SPSS Cetakan Pertama. Yosgakarta: Media Kom.

Purwanto, Djoko. 2008. Fursuan Lengkap Memasubi Dunia Kerja.

Surakarta: Esensi Erlangea Group.
Yulaelawati, Ella. 2004. Kurikulum Dan Pembelajaran (Filosofi, Teori, Dan Aplikasi) Cetakan Pertama. Jakarta: Pakar

Raya. 